\title{
Static and Dynamic Studies of Gasoline in View of its Octane Number and its Toxic Effect
}

\author{
Ashraf Yehia El-Naggar ${ }^{1,2^{*}}$ and Mohamed A. Ebiad ${ }^{2}$ \\ 1-Chemistry Department, Faculty of Science, Taif University, Taif, KSA. \\ 2-Egyptian Petroleum Research Institute EPRI, Nasr City, Cairo, Egypt. \\ *aynaggar361@yahoo.com
}

\begin{abstract}
Gasoline come primarily from petroleum cuts, it is the preferred liquid fuel in our lives. Two gasoline samples of octane numbers 91 and 95 from Saudi Arabia petrol stations were studied. This study was achieved at three different temperatures $20^{\circ} \mathrm{C}, 30^{\circ} \mathrm{C}$ and $50^{\circ} \mathrm{C}$ representing the change in temperatures of the different seasons of the year. Both the evaporated gases of light aromatic hydrocarbons (BTEX) of gasoline samples inside the tank were subjected to analyze qualitatively and quantitatively via capillary gas chromatography. The detailed hydrocarbon composition and the octane number of the studied gasoline samples were determined using detailed hydrocarbon analyzer. The idea of research is indicating the impact of light aromatic compounds in gasoline on the toxic effect of human and environment on the one hand, and on octane number of gasoline on the other hand. Although the value of octane number will be reduced but this will have a positive impact on the environment as a way to produce clean fuel.
\end{abstract}

Key Words:- Gasoline; dynamically; light aromatic hydrocarbons; toxic effect; capillary gas chromatography; detailed hydrocarbon composition; octane number.

\section{Council for Innovative Research}

Peer Review Research Publishing System

\section{Journal: Journal of Advances in Chemistry}

Vol. 4, No. 2

editor@cirworld.com

www.cirworld.com, member.cirworld.com 


\section{Introduction}

For over a century, the internal combustion engine and its fuel, petrol, have had a major effect on our lives. Gasoline is a mixture of over 200 petroleum-derived chemicals plus a few synthetic products that are added to improve fuel performance [1-4]. Gasolines come primarily from petroleum cuts with a range of boiling points from 38 to 150-205 0C and a carbon number distribution of C4-C12 [5, 6].

The most important hazardous components of most gasoline fuels are benzene and many more compounds than just the better known BTEX alkyl benzenes (toluene, xylenes, and ethyl benzene. These aromatics are very harmful and carcinogenic compounds and their high volatility is the source of dangerous because it is easy to transmitted to humans by smell [7, 8]. Workers at petrol station and factories that depend on gasoline exposed to the dangers of aromatic compounds liberated from gasoline fuel that have immediate and future effects of hand, these are articles have a direct relationship with octane number of gasoline fuel. The most common way people are exposed to benzene and other light aromatic hydrocarbons is when they fill their car with gasoline. Benzene evaporates quickly from contaminated water. Benzene vapors are present in exhaust from many industries and automobiles. People who live near highways or industries or petroleum station can be exposed to light aromatic hydrocarbons BTEX. The abundance of aromatic compounds in air must be $0.2 \mathrm{ppm}$, and in water must be $0.1 \mathrm{ppb}$ and if this proportion increased to $100 \mathrm{ppm}$ the following things occur: 1-Shortness of breath and throat 2-headche, loss of balance 3-The effects on the liver and blood pressure 4Irregular beat of the heart. The affects that occur after year:- 1-cancer which occurs after continuous exposure to benzene. 2-effects on the nervous system and blood cells [9].

The impact of aromatic compounds on octane number to existence relationship between them [10 -13]. it has been reduced aromatic compounds or separation part of the gasoline and reformat a small extent so do not affect the quality of fuel, and efficiency of combustion within the engine and other words that it was abandoned for a fraction the value of the octane number, also, at the same time is a bad impact on the environment in terms of high pollutant by vehicle exhausts and petrol station

when the value of octane number will be reduced this will have a negative impact on the combustion of engine to a degree depend on the percentage of liberated light aromatics. In some times as away to reduce aromatic compounds are the product of gasoline with octane number unacceptable which can be way to produce clean fuel. The capillary gas chromatography connected with flame ionization detector [14,15] plays an efficient analytical tool for complete analysis of gasoline fuel using selected ply siloxane capillary column [16]. The main goal of this work is the analysis of gasoline of 91 and $95-\mathrm{ON}$ (octane number) statically and dynamically at three different temperatures $20 \mathrm{oC}, 30 \mathrm{oC}$ and $50 \mathrm{oC}$ and study the impact of light aromatics on the human and on the octane number of engine motor.

\section{Experimental}

\section{Sampling}

For dynamic studies, the volume $4 \mathrm{ml}$ of each gasoline sample was selected for static studies at three different temperatures $20^{\circ} \mathrm{C}, 30^{\circ} \mathrm{C}$ and $50^{\circ} \mathrm{C}$. each temperature was kept at 30 min as constant time.

\section{Gas Chromatography (GC)}

The studied gasoline fuel samples of octane numbers 91 and 95 were subjected to gas chromatography. The instrument used was Clarus-500 gas chromatograph equipped with flame ionization detector (FID) and splitt-aplittless injector. Oven temperature was programmed from $100^{\circ} \mathrm{C}$ to $300^{\circ} \mathrm{C}$ at fixed rate of $3^{\circ} \mathrm{C}$ min- 1 . HP-1 fused silica capillary column $(30 \mathrm{~m} \mathrm{X}$ $0.53 \mathrm{~mm} \times 0.5 \mu \mathrm{m}$ ) was used for the analysis. Helium was used as carrier gas at flow rate $2 \mathrm{ml}$ min -1 , the injector and detector temperatures are 300 and $325^{\circ} \mathrm{C}$ respectively.

\section{Detailed Hydrocarbon Analyzer (DHA)}

The studied gasoline samples were analyzed by the detailed hydrocarbon analyzer (DHA) of model Clarus-500 gas chromatograph. The instrument was equipped with a flame ionization detector, the system was provided with selective column and soft-ware for the DHA. The analyzer is a factory tested by Arnel (Job No 6477-AGC). The column used was tuned $100 \mathrm{~m}$ length and $0.25 \mathrm{~mm}$ internal diameter with a film thickness of $0.5 \mu \mathrm{m}$, the column was coated with polydimethyl siloxane as stationary phase. The analysis was done according to ASTM D-6730 standard method, the DHA data obtained was converted into PIONA results (i.e., paraffins, isoparaffins, olefins, naphthenes and aromatic percentages of each carbon number). The instrument settings were as follows: Carrier gas is helium at a flow rate of $1 \mathrm{ml}$ min-1. Oven Program (ramp 1): from $5^{\circ} \mathrm{C}$ (for $10 \mathrm{~min}$ ) to $48^{\circ} \mathrm{C}$ (for $54: 40 \mathrm{~min}$ ) at a rate of $50 \mathrm{C}$ min-1. The initial temperature was maintained by $\mathrm{CO} 2$ cryogenic system. Oven Program (ramp 2): from $48^{\circ} \mathrm{C}$ to $200^{\circ} \mathrm{C}$ (for $30: 00 \mathrm{~min}$ ) at a rate of $1.40 \mathrm{C}$ min-1.

\section{Results and Discussions}

\section{Physical and chemical properties of gasoline}

Information regarding the physical and chemical properties for the gasoline mixture is located in Table (1). In cases where data are not available for gasoline, ranges are given to indicate the different values for the individual components [17]. 
Table (1) Physical and Chemical Properties of Gasoline [17]

\begin{tabular}{|l|l|}
\hline Property & Information \\
\hline Molecular weight & $85-100$ \\
\hline Physical state & Liquid \\
\hline Boiling point & $\begin{array}{l}\text { Initially, } 39^{\circ} \mathrm{C} \mathrm{After} 10 \% \text { distilled, } 60^{\circ} \mathrm{C} \\
\text { After } 50 \% \text { distilled, } 110^{\circ} \mathrm{C} \mathrm{After} 90 \% \\
\text { distilled, } 170^{\circ} \mathrm{C} \text { Final boiling point, } 204^{\circ} \mathrm{C}\end{array}$ \\
\hline Density & $0.7-0.8 \mathrm{~g} / \mathrm{cm}$ \\
\hline Color & Gasoline odor \\
\hline Solubility in water at $20 \mathrm{oC}$ & Insoluble \\
\hline Solubility in organic solvent & $\begin{array}{l}\text { Absolute alcohol, ether, chloroform, } \\
\text { benzene }\end{array}$ \\
\hline Flashpoint & -46 oC \\
\hline Flammability limits & $1.4-7.4 \%$ \\
\hline Autoignition temperature & $280-486$ oC \\
\hline Explosive limits & $1.3-6.0 \%$ \\
\hline
\end{tabular}

The capillary gas chromatographic analysis of the studied liquid gasoline fuels of octane numbers 91 and 95 were shown in figures 1 and 2. The chromatograms show the composition of gasoline mixture, normal paraffines, iso-paraffines and aromatics, the composition of gasoline contains hydrocarbons starting from ethane to pentadecane.

Summary reports of the studied gasoline samples of octane numbers (ON) 91 and 95 were achieved using the modern analytical GC technique named detailed hydrocarbon analyzer (DHA) and the results were given in Tables 2, 3. It has been found that the studied two gasoline samples of ON 91 and 95 contain aromatics 28.8 and 24.9 wt \% respectivelly, the major amount of these aromatic are benzene and alkyl benzenes named BTEX (benzene, toluene, ethyl benzene and xylenes), and poly aromatics represents the minor amounts. The high volatility of the BTEX is the source of dangerous because it is easy to transmitted by smell to workers at petrol station and People who live near highways or petroleum station. These aromatics are very harmful and carcinogenic compounds. Gasoline is a volatile, flammable liquid obtained from distilling and refining petroleum, or crude oil, so, the compositions (paraffines, iso-paraffines and oliffines) of the studied gasoline samples are nearly the same, this was indicated from the total carbon and total hydrogen percentages given in Tables 2 and 3. The only differences in their compositions is the weight percentage of aromatics and the additive Tert Butyl Ether (TBE) to increase octane number.

\section{GC studies of gas, liquid, and stream composition of gasoline fuels 91 and 95 at 20 ${ }^{\circ} \mathrm{C}, 30^{\circ} \mathrm{C}$ and $50^{\circ} \mathrm{C}$}

Gas chromatographic analysis of gas and liquid in gasoline 91 and gasoline 95 statically at 20 oC, 30 oC and 50 oC was achieved and one example from them was given in Table 4. The composition of gas sample contains hydrocarbons starting from ethane to dodecane including light aromatics BETX, toluene followed by benzene represents the high value compared with other aromatics. Iso pentane and iso hexane represent the maximum mole percent in the liberated gas from gasoline inside tank, the rest of the percentage distributed on the other components. The composition of liquid sample in gasoline contains hydrocarbons starting from ethane to pentadecane including high percentage of light aromatics BETX. The weight percentages of the light aromatics BTEX are given in Tables 5 and 6 . Toluene exhibits the highest percentage of aromatics than the other aromatics followed by xylenes. The stream composition was calculated by the combination of the all compositions of liberated gases and that in liquid gasoline inside the tank.

The amounts of total light aromatics liberated from liquid gasoline fuels 91 inside care tank statically at 20 oC, 30 oC and 50 oC reaches $1.529 \%, 1.956 \%$ and $2.216 \%$ respectively, and that of gasoline 95 are $0.822,0.959$ and 1.320 respectively. It is clear that the liberated light aromatics from liquid gasoline fuel inside car tank increase as a function of temperatures. These amounts have harmful effect on human health and environment and octane number, in addition the value of octane number was decreased followed by decreasing the efficiency of engine motor. 
Figure 1. Chromatogram of gasoline fuel of Octane Number 91

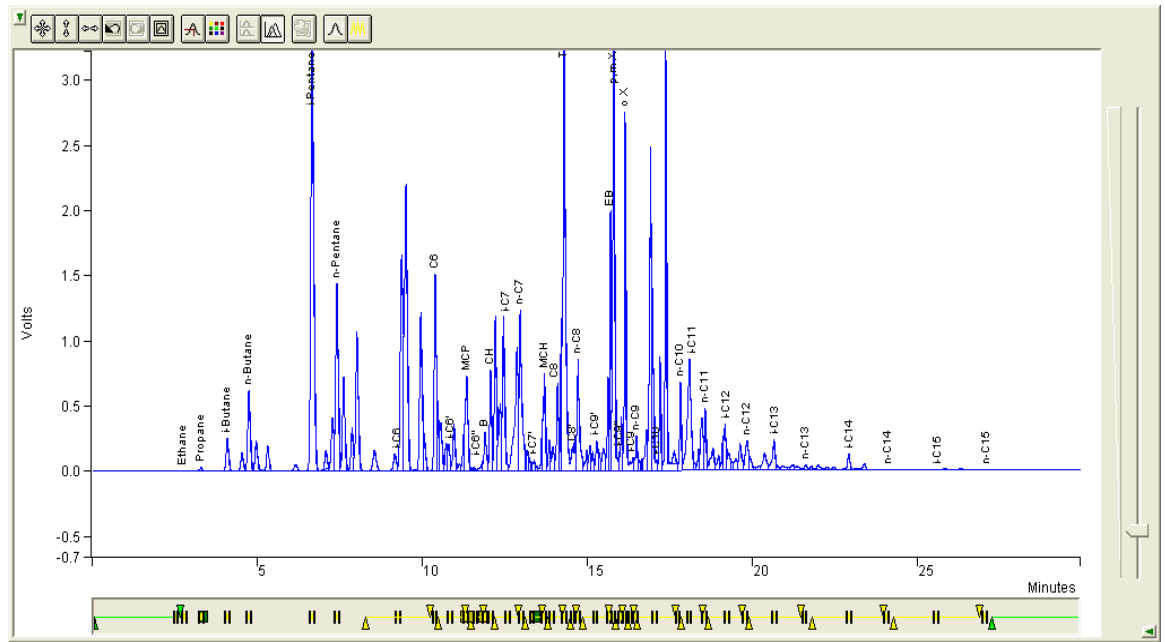

Table 2 Summary report of gasoline sample of Octane No. 91

\begin{tabular}{|c|c|c|}
\hline Group Type & Total (mass\%) & Total (vol\%) \\
\hline Paraffins & 10.544 & 11.766 \\
\hline I-paraffins & 36.853 & 39.751 \\
\hline Olefins & 13.911 & 14.919 \\
\hline Naphthenes & 5.665 & 5.393 \\
\hline Aromatics & 28.870 & 22.292 \\
\hline Total C14+: & 0.000 & 0.000 \\
\hline Total Unknowns & 1.752 & 1.576 \\
\hline Grand Total & 100.000 & 100.000 \\
\hline methyl-t-butylether & 4.405 & 4.303 \\
\hline Average Molecular Weight & & \\
\hline Relative Density & & \\
\hline $\begin{array}{l}\text { Vapor Pressure } \\
\left.\text { (psi @ } 100^{\circ} \mathrm{F}\right)\end{array}$ & & \\
\hline Octane Number (calculated) & & \\
\hline Percent Carbon & & \\
\hline Percent Hydrogen & & \\
\hline Bromine Number & & \\
\hline
\end{tabular}


Figure 2. Chromatogram of gasoline fuel of Octane Number 95

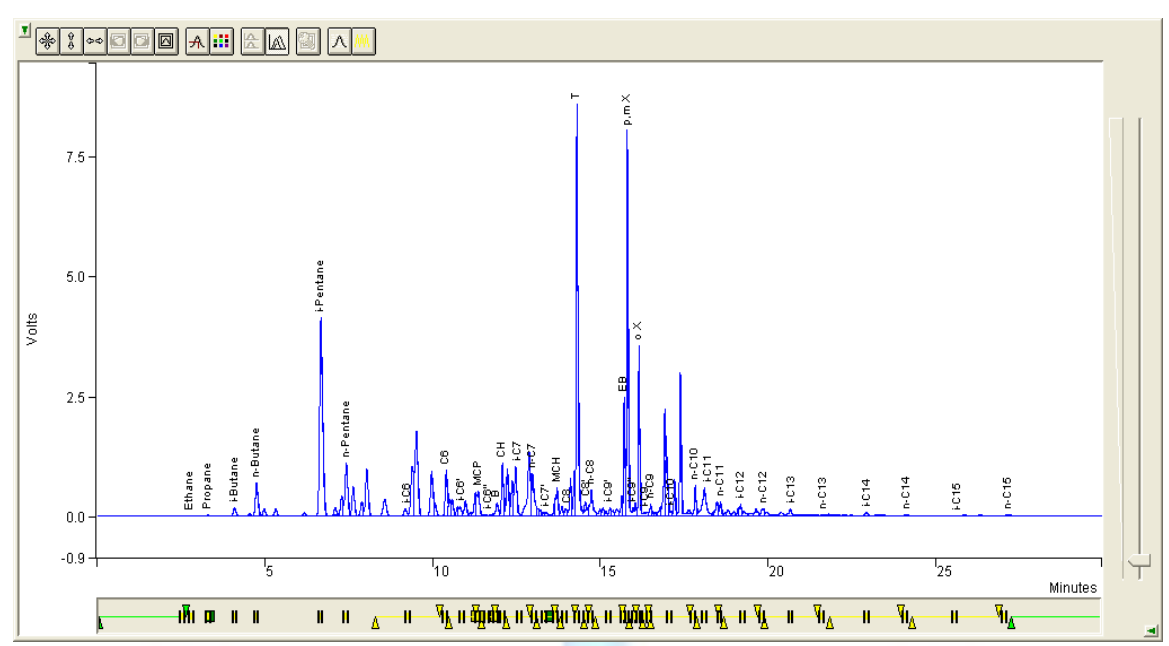

\section{With respect to human health,}

The concentrations of total volatile aromatic compounds BETX liberated from liquid gasoline fuels 91 aqnd 95 inside car tank are ranged from 0.822 to $2.216 \%$. These aromatics are very harmful and carcinogenic compounds and their high volatility is the source of dangerous because it is easy to transmitted to humans by smell. workers at petrol station and people who live near highways or petroleum station can be exposed to these light aromatic hydrocarbons

Table 3. Summary Report of gasoline sample of Octane No. 95

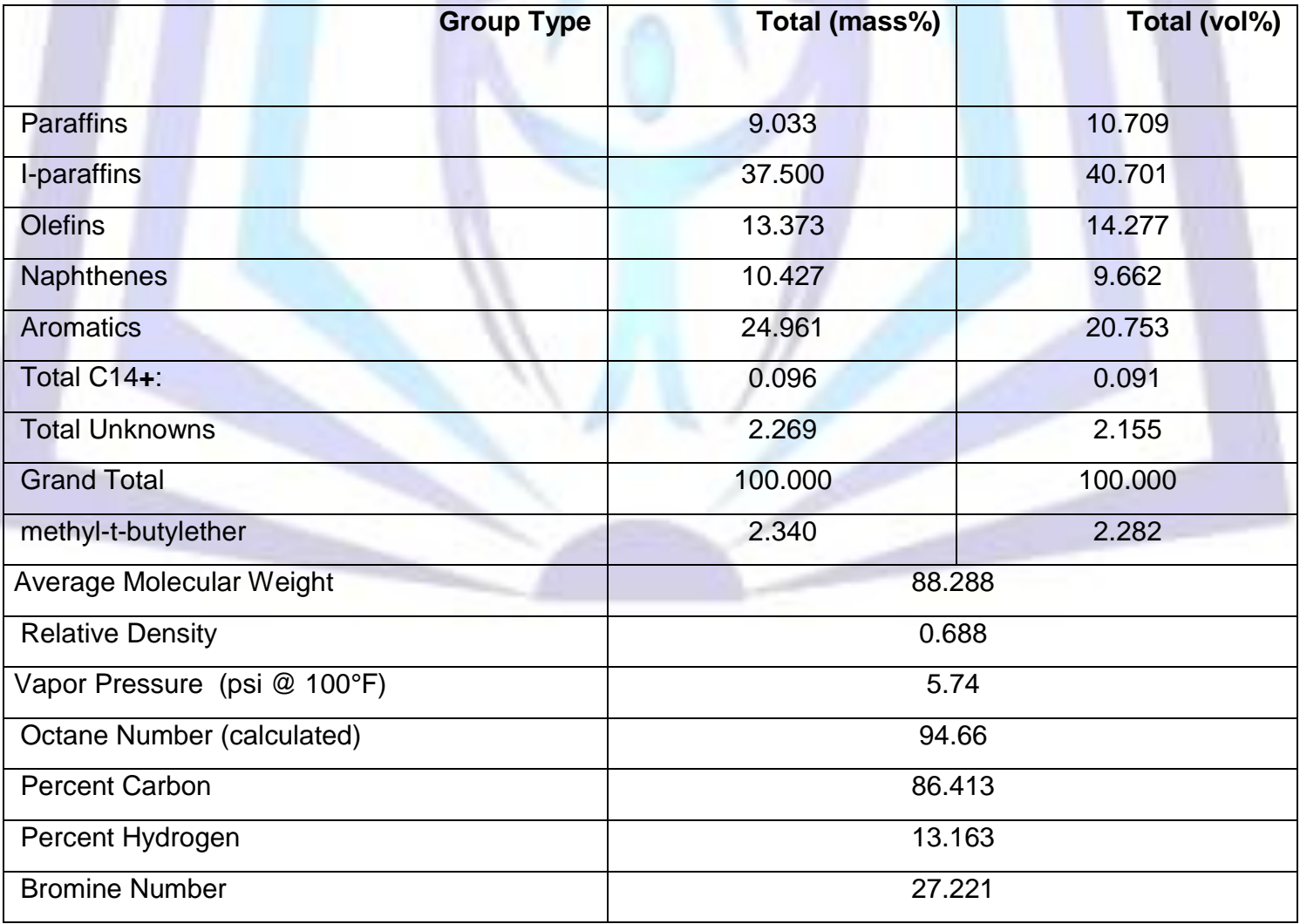

Occupational exposure limits [18] (OEL) are set to protect workers from excessive exposure to toxic chemicals in the workplace. An OEL defines the maximum average concentration of a chemical in the breathing zone acceptable for a normal 8-hour working day for 5 days a week. the OEL for benzene only has been ranging from 0.1 to 1 ppm in 2008 [19]. Here we study the effect of all light aromatic hydrocarbons like benzene, toluene, ethyl benzene and xylenes (BTEX). So, the total concentration of BTEX has very harmful effect on workers at petrol station. 


\section{With respect to octane number}

The octane number of gasoline is one of the most important parameter determining the fuel quality. the octane number of a gasoline is a measure of its resistance to detonation $[20,21]$. The octane number of an engine is determined according to the engine design and compression ratio. The weather, driving conditions, and mechanical conditions of the engine are some examples that will be able to influence this requirement.

The percentage of the volatile aromatic compounds BETX is one of the main factors affecting the octane number value. So, the liberated aromatics from liquid gasoline fuel into the space above liquid inside car tank have pronounced effect on decreasing the octane number as given in Tables 5 and 6 . This reflecting on decreasing the efficiency of combustion within the engine to the extent of liberated light aromatics from liquid gasoline fuel. The octane number decreases with increasing temperatures.

Table 4. Gas chromatographic analysis of a gas, liquid, and stream composition of gasoline sample

$(\mathrm{ON}=91)$ at $20^{\circ} \mathrm{C}$

\begin{tabular}{|c|c|c|c|c|c|c|}
\hline \multirow[t]{2}{*}{ Components } & \multicolumn{2}{|c|}{ Gas Sample } & \multicolumn{2}{|c|}{ Liquid Sample } & \multicolumn{2}{|c|}{ Stream Composition } \\
\hline & Mol. \% & Wt. \% & Mol. \% & Wt. \% & Mol. \% & Wt. \% \\
\hline Ethane & 0.033 & 0.014 & 0.011 & 0.003 & 0.011 & 0.004 \\
\hline Propane & 1.054 & 0.638 & 0.027 & 0.012 & 0.039 & 0.018 \\
\hline i-Butane & 5.782 & 4.609 & 0.429 & 0.261 & 0.491 & 0.299 \\
\hline Butene & 1.311 & 1.009 & 0.149 & 0.088 & 0.163 & 0.096 \\
\hline n-Butane & 15.659 & 12.481 & 1.972 & 1.200 & 2.130 & 1.300 \\
\hline i-pentane & 43.086 & 42.631 & 14.321 & 10.814 & 14.653 & 11.096 \\
\hline pentene & 0.886 & 0.852 & 1.587 & 1.165 & 1.579 & 1.162 \\
\hline n-Pentane & 2.396 & 2.371 & 3.189 & 2.408 & 3.180 & 2.408 \\
\hline i-Hexanes & 21.071 & 24.902 & 11.321 & 10.211 & 11.434 & 10.341 \\
\hline n-Hexane & 1.615 & 1.909 & 2.457 & 2.216 & 2.448 & 2.214 \\
\hline Methyl cyclopentane & 3.978 & 4.591 & 4.645 & 4.092 & 4.637 & 4.096 \\
\hline Benzene & 0.606 & 0.649 & 2.040 & 1.668 & 2.023 & 1.659 \\
\hline Cyclohexane & 0.405 & 0.467 & 2.087 & 1.839 & 2.068 & 1.827 \\
\hline Heptanes & 0.893 & 1.228 & 8.072 & 8.466 & 7.989 & 8.402 \\
\hline Methyl cyclohexane & 0.093 & 0.122 & 0.991 & 0.998 & 0.981 & 0.990 \\
\hline Toluene & 0.805 & 1.018 & 15.220 & 14.678 & 15.053 & 14.557 \\
\hline Octane & 0.162 & 0.254 & 3.139 & 3.753 & 3.105 & 3.722 \\
\hline Ethyl-benzene & 0.032 & 0.047 & 4.407 & 4.897 & 4.357 & 4.854 \\
\hline p,m-xylene & 0.070 & 0.102 & 10.495 & 11.662 & 10.374 & 11.559 \\
\hline o-xylene & 0.016 & 0.023 & 0.532 & 0.591 & 0.526 & 0.586 \\
\hline Nonanes & 0.042 & 0.073 & 5.545 & 7.444 & 5.482 & 7.379 \\
\hline Decanes & 0.004 & 0.007 & 4.531 & 6.748 & 4.479 & 6.689 \\
\hline Undecanes & 0.001 & 0.003 & 2.075 & 3.395 & 2.051 & 3.365 \\
\hline Dodecanes & 0.000 & 0.001 & 0.531 & 0.947 & 0.525 & 0.938 \\
\hline Tridecanes & 0.000 & 0.000 & 0.173 & 0.335 & 0.171 & 0.332 \\
\hline Tetradecanes & 0.000 & 0.000 & 0.046 & 0.095 & 0.045 & 0.094 \\
\hline Pentadecanes & 0.000 & 0.000 & 0.006 & 0.014 & 0.006 & 0.014 \\
\hline Total & 100.000 & 100.00 & 100.000 & 100.000 & 100.000 & 100.000 \\
\hline Mol. Wt. & 72. & & 95. & & 95. & \\
\hline
\end{tabular}




\begin{tabular}{|c|c|c|c|}
\hline Equ.liq.density & 0.6364 & 0.7409 & 0.7398 \\
\hline $\begin{array}{l}\text { Total WT of aromatic } \\
\text { (BTEX) }\end{array}$ & & & $1.765 \mathrm{mg}$ \\
\hline
\end{tabular}

Table 5. GC of BETX (Wt \%) in gas, liquid and stream composition of gasoline sample $(\mathrm{ON}=91)$ Statically at $20{ }^{\circ} \mathrm{C}, 30^{\circ} \mathrm{C}$ and $50{ }^{\circ} \mathrm{C}$

\begin{tabular}{|c|c|c|c|c|c|c|c|c|}
\hline $\begin{array}{l}\text { Tempe- } \\
\text { ratures }\end{array}$ & Sample & B & $\mathbf{T}$ & E & $\mathrm{X}$ & $\begin{array}{l}\text { Total } \\
\text { BTEX }\end{array}$ & $\begin{array}{l}\text { Octane } \\
\text { No. } \\
\text { Before } \\
\text { Evapor- } \\
\text { ation }\end{array}$ & $\begin{array}{l}\text { Octane } \\
\text { No. } \\
\text { After } \\
\text { Evapor- } \\
\text { ateion }\end{array}$ \\
\hline \multirow{3}{*}{$20^{\circ} \mathrm{C}$} & Gas & 0.649 & 1.018 & 0.047 & 0.125 & 1.839 & \multirow{3}{*}{90.44} & \multirow{3}{*}{89.75} \\
\hline & Liquid & 1.668 & 14.678 & 4.897 & 12.253 & 33.496 & & \\
\hline & $\begin{array}{c}\text { Stream } \\
\text { composition }\end{array}$ & 1.659 & 14.557 & 4.854 & 12.145 & 33.215 & & \\
\hline \multirow{3}{*}{$30^{\circ} \mathrm{C}$} & Gas & 0.753 & 1.055 & 0.040 & 0.108 & 1.956 & \multirow{3}{*}{90.44} & \multirow{3}{*}{89.67} \\
\hline & Liquid & 2.108 & 13.776 & 3.650 & 15.417 & 34.951 & & \\
\hline & $\begin{array}{c}\text { Stream } \\
\text { composition }\end{array}$ & 2.081 & 13.515 & 3.576 & 15.103 & 34.275 & & \\
\hline \multirow{3}{*}{$50^{\circ} \mathrm{C}$} & Gas & 0.831 & 1.197 & 0.052 & 0.136 & 2.216 & \multirow{3}{*}{90.44} & \multirow{3}{*}{89.32} \\
\hline & Liquid & 2.280 & 14.318 & 5.002 & 20.104 & 41.704 & & \\
\hline & $\begin{array}{c}\text { Stream } \\
\text { composition }\end{array}$ & 2.145 & 13.090 & 4.539 & 18.236 & 38.010 & & \\
\hline
\end{tabular}

Table 6. GC studies of gas, liquid, and stream composition of gasoline fuel 95 at $20 \circ \mathrm{C}, 30 \mathrm{oC}$ and $50 \mathrm{oC}$

\begin{tabular}{|c|c|c|c|c|c|c|c|c|}
\hline $\begin{array}{c}\text { Temper- } \\
\text { atures }\end{array}$ & Sample & $\mathbf{B}$ & $\mathbf{T}$ & $\mathbf{E}$ & $\mathbf{X}$ & $\begin{array}{c}\text { Total } \\
\text { BTEX }\end{array}$ & $\begin{array}{c}\text { Octane No. } \\
\text { Before } \\
\text { Evaporation }\end{array}$ & $\begin{array}{c}\text { Octane No. } \\
\text { After } \\
\text { Evaporateion }\end{array}$ \\
\hline \multirow{2}{*}{$\mathbf{2 0}{ }^{\circ} \mathbf{C}$} & Gas & 0.360 & 0.375 & 0.018 & 0.069 & 0.822 & & \\
\cline { 2 - 7 } & Liquid & 1.749 & 8.684 & 3.304 & 10.361 & 23.762 & \multirow{2}{*}{94.66} & 93.90 \\
\cline { 2 - 7 } & $\begin{array}{c}\text { Stream } \\
\text { composition }\end{array}$ & 1.729 & 8.565 & 3.256 & 10.212 & 23.766 & & \\
\hline \multirow{2}{*}{$\mathbf{3 0}{ }^{\circ} \mathbf{C}$} & Gas & 0.416 & 0.444 & 0.022 & 0.077 & 0.959 & & \\
\hline
\end{tabular}




\begin{tabular}{|c|c|c|c|c|c|c|c|c|}
\hline & Liquid & 2.072 & 11.230 & 3.317 & 17.100 & 33.719 & \multirow{2}{*}{94.66} & 93.82 \\
\cline { 2 - 7 } & $\begin{array}{c}\text { Stream } \\
\text { composition }\end{array}$ & 2.016 & 10.869 & 3.206 & 16.530 & 32.621 & & \\
\hline \multirow{2}{*}{$\mathbf{5 0} \mathbf{~}^{\circ} \mathbf{C}$} & Gas & 0.528 & 0.554 & 0.048 & 0.119 & 1.320 & & \multirow{2}{*}{93.52} \\
\cline { 2 - 7 } & Liquid & 2.921 & 7.927 & 6.543 & 23.042 & 40.433 & \\
\cline { 2 - 7 } & $\begin{array}{c}\text { Stream } \\
\text { composition }\end{array}$ & 2.653 & 7.104 & 5.818 & 20.481 & 36.056 & & \\
\hline
\end{tabular}

\section{Conclusion}

1. The total liberated light aromatic hydrocarbons BTEX from gasoline fuel inside car tank in dynamic studies exhibit higher values than that in static studies may be due to the liberated gases increase with shaking. The percentages of BTEX increase as a function of shaking temperature. toluene followed by benzene represents the high value compared with other light aromatics.

2. The high volatility of the BTEX is the source of dangerous because it is easy to transmitted by smell to workers at petrol station and People who live near highways or petroleum station causing an immediate and future effects of hand and harmful to the environment. These liberated light aromatics from liquid gasoline fuel into the space above liquid fuel inside car tank produce a gasoline with octane number unacceptable which decrease the efficiency of combustion within the engine.

3. The liberating aromatic compounds exhibit higher values in summer than in winter due to the liberation of light aromatics increase as a function of temperatures. These accompanied with increasing the chance of suffering the workers at petrol station with harmful effect and decreasing the value of octane number.

\section{References}

[1] Lane GC. gasoline and other motor fuels. In Grayson M, Eckroth D, eds. Kirk - Othmer encyclopedia of chemical technology. New York, NY: Gohn Willey and Sons, 652-676, 694-695, 1980.

[2] Domask W.G. Introduction to petroleum hydrocarbons; Chemistry and composition in relation to petroleum derived fuels and solvents. In Mehiman M.A.Hemstreet GP. Thorpe GG, et al, eds, 1984. ed. New York, NY: Van Nostrand Reinhold Company, 491-493, 1973.

[3] Henderson H.T., Creek W., Calif. Assignor to shell Oil Company. Gasoline Composition, Patent no. 3,179,506, 1965.

[4] Yacobucci B.D.and Womach,J.Fuel ethanol background and puplic policy issues. Available from: : http://www.cnie.org/NLE/CRSreports/energy/eng.59.cfn.2006.

[5] Gasoline blending streams test plane submitted to the USEPA by the American petroleum institute petroleum HPV Tosting Group, 2001.

[6] Air Force. Gasoline. In: The installation restoration program toxicology guide. Volume 4.Contract no. DE-AC05840R21400. Wright-Patterson Air Force Base, OH. Document no. 65-I-65-46, 1989.

[7] Sidhpuria K.B. and Parikh P.A., Bulletin of the Catalysis Society of India Vol. 3, 68-71, 2004.

[8] Jorunn K, Trond R, Bjørn T. G, Bente E. M., Magne B., Øystein B., The Open Hematology Journal, Vol. 2, 87-102, 2008.

[9] Kirchstetter, T.W., B.C. Singer, R.A. Harley, G.R. Kendall and W. Chan Environmental Science \& Technology, Vol. 30, pp 661-670, 1996.

[10] Downs D., and Walsh A.D., Knock in Internal Combustion Engines, Nature, Vol. 163, p 370, 1949. edition, 1992.

[11] Midgley T., Jr.Ind.Eng.Chem. Vol.31 P.504-506, 1993.

[12] Midgley: Saint or Serpent? .Kauffman G.B., Chemtech, December p.717-725, 1989.

[13] Edgar G., Measurement of the knock characteristics of gasoline in terms of a standard fuel. Ind. Eng. Chem. v.19 p.145-146, 1927. 
[14] El-Naggar A.Y., Petroleum Science and Technology, Vol. 24,41-50, 2006.

[15] Pavlova A. and Ivanova R., ACTA CHROMATOGRAPHICA, NO. 13, 215-225, 2003.

[16] El-Naggar A.Y., Petroleum Science and Technology, Vol. 24,753-767, 2006.

[17]Toxicological profiler for gasoline, U.S. department of health and human services (Public health service) June 1995.

[18] Jorunn Kirkeleit1, Trond Riise1, Bjørn Tore Gjertsen2, Bente E. Moen1, Magne Bråtveit1, Øystein Bruserud2, The Open Hematology Journal, Vol. 2, 87-102, 2008.

[19] Capleton AC, Levy LS. An overview of occupational benzene exposures and occupational exposure limits in Europe and North America. Chem Biol Interact, Vol. 153 - 4, 43-53, 2005.

[20] C. Twu, J. Coon, A Generalized Interaction Method for the Prediction of Octane Numbers for Gasoline Blends, imulation Science Inc., pp. 1-18, 1998.

[21] K. Mogi, H. Katsushi, K. Arisawa, H. Kobayashi, Analysis and avoidance of pre-ignition in spark-ignition engines, JSAE Review (19) 9-14, 1998. 